\title{
Anti-cancer effects of bortezomib against chemoresistant neuroblastoma cell lines in vitro and in vivo
}

\author{
MARTIN MICHAELIS $^{1}$, IDUNA FICHTNER ${ }^{2}$, DIANA BEHRENS ${ }^{2}$, WOLFRAM HAIDER ${ }^{4}$, \\ FLORIAN ROTHWEILER $^{1}$, ANDREAS MACK ${ }^{3}$, JAROSLAV CINATL ${ }^{1}$, \\ HANS WILHELM DOERR ${ }^{1}$ and JINDRICH CINATL $\mathrm{Jr}^{1}$
}

\author{
${ }^{1}$ Institut für Medizinische Virologie, Klinikum der Johann Wolfgang Goethe-Universität, Paul Ehrlich-Str. 40, \\ D-60596 Frankfurt am Main; ${ }^{2}$ Max-Delbrück-Center for Molecular Medicine, Robert-Rössle-Str. 10, \\ D-13125 Berlin; ${ }^{3}$ Gamma Knife Zentrum Frankfurt, Schleusenweg 2-16, D-60528 Frankfurt am Main; \\ ${ }^{4}$ Institute for Animal Pathology, Schönhauser Str. 62, D-13127 Berlin, Germany
}

Received August 29, 2005; Accepted October 14, 2005

\begin{abstract}
The proteasome inhibitor bortezomib (Velcade ${ }^{\circledR}$ ) was recently approved for the treatment of therapy-refractive multiple myeloma and is under investigation for numerous other types of cancer. A phase I clinical trial in paediatric patients resulted in tolerable toxicity. Since the emergence of chemoresistance represents one of the major drawbacks in cancer therapy, we investigated the influence of bortezomib on multi-drug resistant human neuroblastoma cell lines characterised by P-glycoprotein expression and p53 mutation. Nanomolar concentrations of bortezomib inhibited the cell cycle and induced apoptosis in chemosensitive as well as in chemoresistant cell lines. In vivo growth of chemosensitive and chemoresistant neuroblastoma cell lines was inhibited to a similar extent. In addition, bortezomib inhibited vessel formation in neuroblastoma xenografts. These findings and the favourable toxicity profile of bortezomib in children make it reasonable to further pursue additional development of the drug for the treatment of neuroblastoma and other paediatric solid tumours.
\end{abstract}

\section{Introduction}

High risk neuroblastoma patients are treated with multimodality therapeutic protocols that use high-dose chemotherapy with autologous bone marrow or stem-cell transplantation (1-3). However, the prognosis for children older than 1 year with metastatic, stage IV neuroblastoma has only improved

Correspondence to: Dr Jindrich Cinatl Jr, Institut für Medizinische Virologie, Klinikum der Johann Wolfgang Goethe-Universität, Paul Ehrlich-Str. 40, D-60596 Frankfurt am Main, Germany

E-mail: cinatl@em.uni-frankfurt.de

Key words: bortezomib, neuroblastoma, multidrug resistance, chemoresistance, doxorubicin, vincristine marginally, and the overall long-term disease-free survival rate still remains low. After initial response to chemotherapy, drug resistance arises in the majority of stage IV and in relapse neuroblastoma disease (4). Thus, the search for effective treatments especially those active against tumours resistant to conventionally used drugs remains a primary goal.

Bortezomib (Velcade ${ }^{\circledR}$, formerly PS-341), a dipeptidyl boronic acid, is a novel agent that exerts its anti-cancer effects through specific and selective inhibition of the chemotryptic enzyme activity of the $26 \mathrm{~S}$ proteasome $(5,6)$. The $26 \mathrm{~S}$ proteasome pathway plays a pivotal role in the regulated degradation of proteins involved in the cell cycle control and tumour growth, including nuclear factor $\kappa \mathrm{B}, \mathrm{p} 53$, and the cyclin-dependent kinase inhibitor p21 $(5,6)$. Preclinical results show that bortezomib suppresses cancer cell growth, induces apoptosis, overcomes resistance to standard chemotherapy agents and radiation therapy, and inhibits angiogenesis in different types of adult cancer (7-9). Numerous clinical trials that evaluate the efficacy of bortezomib against these cancers have been initiated (6). In a recent large multicenter phase II clinical trial approximately one third of patients with advanced multiple myeloma had a significant response to therapy with bortezomib (10). On the basis of these findings, bortezomib was approved in the USA and the EU for the treatment of patients with multiple myeloma who had relapsed after at least two prior treatment regimens and had evidence of resistance to their last treatment (6).

A recent phase I study of bertozomib in paediatric patients with refractory solid tumours (including two patients with neuroblastoma) demonstrated that the drug is well tolerated with minimal systemic toxicity (11). Dose-dependent inhibition of $20 \mathrm{~S}$ proteasome activity was found in this phase I trial after drug administration. Since the phase I trial involved heavily pretreated patients it is probable that tumour cells exerted resistance to conventionally used drugs. However, whether such resistance may influence sensitivity of solid paediatric tumours to bortezomib has not been studied yet. In order to directly address the sensitivity of chemoresistant 
NB cells to bortezomib, we investigated anti-tumoural effects of the drug in well established resistance models of human tumour cell lines in vitro and in nude mice.

\section{Materials and methods}

Materials. Bortezomib (Velcade ${ }^{\circledR}$ ) was obtained from JanssenCilag, Neuss, Germany. Solutions of vincristine (SigmaAldrich, Deisenhofen, Germany) and doxorubicin (Cell Pharm, Hannover, Germany) were prepared in accordance to the manufacturer's instructions.

Cells. The N-myc amplified cell line UKF-NB-3 was established from metastases harvested in relapse of a patient with Evans stage 4 NB (12). The parental cells were exposed to increasing concentrations of the respective drug and maintained to grow in the presence of $20 \mathrm{ng} / \mathrm{ml}$ of doxorubicin (UKFNB- $3^{r} \mathrm{DOX}^{20}$ ) or $10 \mathrm{ng} / \mathrm{ml}$ vincristine (UKF-NB- $3^{\mathrm{r}} \mathrm{VCR}^{10}$ ), as described previously (12-15). IMR-32 cells and $\mathrm{Be}(2)-\mathrm{C}$ cells were obtained from ATCC (Manassass, VA, USA). All cell lines were propagated in IMDM supplemented with $10 \%$ FBS, $100 \mathrm{IU} / \mathrm{ml}$ penicillin and $100 \mu \mathrm{g} / \mathrm{ml}$ streptomycin at $37^{\circ} \mathrm{C}$.

UKF-NB-3 cells neither express P-glycoprotein (P-gp) nor harbour a p53 mutation. UKF-NB-3 ${ }^{\mathrm{r}} \mathrm{DOX}{ }^{20}$ cells show increased expression of functional P-gp and wild-type p53. UKF-NB- $3^{r} V_{C R}{ }^{10}$ cells are characterised by $\mathrm{P}$-gp expression and p53 mutation (12). Be(2)-C cells express high amounts of P-gp (16) whereas IMR-32 do not express P-gp (17). $\mathrm{Be}(2)-\mathrm{C}$ cells express mutated p53 (18) whereas IMR-32 cells express wild-type p53 $(19,20)$. Table I shows the P-gp and p53 status of the investigated cell lines.

MTT assay. Cell viability was investigated using the modified MTT assay (21), as described prviously (14). Cells were grown in 96-well plates with and without addition of drugs. After the incubation period, MTT reagent was added for $4 \mathrm{~h}$. Thereafter, $100 \mu 1$ of SDS solution $(20 \%$ SDS in a $1: 1$ $\mathrm{DMF} / \mathrm{H}_{2} \mathrm{O}$ solution) was added for further $4 \mathrm{~h}$. Plates were read on a multiwell scanning spectrophotometer at the wavelength of $550 \mathrm{~nm}$ and the reference wavelength of $620 \mathrm{~nm}$. Cell viability was determined as the relative reduction of the amount of MTT reduced by cells to its blue formazan derivative, which correlates with the amount of viable cells in relation to cell control.

Cell cycle. The cell cycle was determined using a commercial kit (BD Biosciences, Heidelberg, Germany) following the manufacturer's instructions as described before (22). The assay is based on the simultaneous detection of bromodeoxyuridine (BrdU) incorporation in the DNA after pulse-labeling for 30 min of dividing cells and detection of the cellular DNA content by staining with 7-amino-actinomycin. This combination allows the characterisation of cells that actively synthesise DNA in terms of their cell cycle position (i.e. $\mathrm{G} 0 / 1, \mathrm{~S}$, or $\mathrm{G} 2 / \mathrm{M}$ phases) by flow cytometry.

Apoptosis. Apoptotic cells were detected as the cells with fractional DNA content ('sub-G1' cell subpopulation). Cells were fixed with $70 \%$ ethanol $(\mathrm{v} / \mathrm{v})$ for $2 \mathrm{~h}$ at $-20^{\circ} \mathrm{C}$. The cellular DNA was stained using propidium iodide $(20 \mu \mathrm{g} / \mathrm{ml})$ and analysed by by flow cytometry (FacsCalibur, BD Biosciences, Heidelberg, Germany).

Animal experiments. Female NMRI:nu/nu mice (Taconic Europe, Ry, Denmark) weighing between 25 and $30 \mathrm{~g}$ received $1 \times 10^{7}$ UKF-NB-3, UKF-NB- $3^{\mathrm{r} D O X^{20}}$, or UKF-NB$3^{\mathrm{r} V C R}{ }^{10}$ cells together with Matrigel $(1+1)$ in a total volume of $100 \mu \mathrm{l}$ subcutaneously into the left flank. Treatment of mice started at palpable tumour size (about $0.05 \mathrm{~cm}^{3}-0.1 \mathrm{~cm}^{3}$ ). This day was defined as day 0 . Bortezomib-treated mice received six tail vein injections of bortezomib $(1 \mathrm{mg} / \mathrm{kg}$ in $200 \mu \mathrm{l} / 20 \mathrm{~g}$ body weight of saline) at day $0,3,6,9,12$, and 15. Control animals received tail vein injections of the same volume of saline at day $0,3,6,9,12$, and 15 . Tumour volumes and body weights were determined twice per week. Mice were held under germ-poor standardised and controlled environmental conditions. In accordance with the German Tierschutzgesetz, the experiments were finished when the tumour sizes exceeded $1 \mathrm{~cm}^{3}$. To detect haematological toxicity blood parameters (WBC, white blood cells; RBC, red blood cells; HGB, haemoglobin; HCT, haematocrit; PLT, platelets; MCV, mean corpuscular volume; $\mathrm{MCH}$, mean corpuscular haemoglobin) were examined 3-5 days after first bortezomib therapy. For that purpose blood was taken from the retrobulbar venous plexus of anaesthetised mice.

After the end of experiments, tumours were excised and cut into two pieces. One piece was embedded in paraffin. Two $\mu \mathrm{m}$ slides were stained with haematoxylin/eosin and investigated for necrosis (indicated by homogeneous eosinophilic areas), mitoses (indicated by mitotic figures consisting of condensed chromosomes), apoptotic cells (indicated by cell shrinkage and condensed chromosomes) and infiltrative growth into the surrounding tissue. Ten visual fields were examined by magnification $\mathrm{x} 400$. Apoptosis and mitoses were classified in a blinded manner to low grade (1-2 mitoses/ apoptotic cells/visual field), medium grade (3-5 mitoses/ apoptotic cells/visual field), and high grade ( $>5$ mitoses/ apoptotic cells/visual field). The tumour microvessel densities were determined at cryoslides of tumours with a murine antibody to CD31 (BD Pharmingen). The staining was performed with a secondary horse radish conjugated antibody (Dako).

\section{Results}

Influence of bortezomib on neuroblastoma cell viability in vitro. Different neuroblastoma cells were incubated for five days with bortezomib, vincristine, or doxorubicin. $\mathrm{IC}_{50}$-values are presented in Table I. UKF-NB- $3^{r}$ DOX ${ }^{20}$, UKF-NB- $3^{r} V_{C R}{ }^{10}$, and $\mathrm{Be}(2)-\mathrm{C}$ cells proved to be resistant to vincristine or doxorubicin treatment whereas UKF-NB-3 and IMR-32 cells were sensitive to both drugs. In contrast, bortezomib strongly impaired the viability of all five cell lines tested in nanomolar concentrations. The $\mathrm{IC}_{50}$ value of bortezomib-treated UKFNB- $3^{\mathrm{r}} \mathrm{DOX}^{20}$ cells $(4.00 \pm 0.32 \mathrm{nM})$ was in the range of the $\mathrm{IC}_{50}$ values of the chemosensitive cell lines UKF-NB-3 and IMR-32. This shows that the cytotoxic effects of bortezomib are not affected by P-gp expression. In contrast, the p53mutated cell lines $\mathrm{Be}(2)-\mathrm{C}$ and UKF-NB- $3^{\mathrm{r}} \mathrm{VCR}^{10}$ showed an about 2-fold decreased sensitivity to bortezomib treatment. 
Table I. P-gp expression, p53-status, and sensitivity to bortezomib, doxorubicin, or vincristine of the cell lines investigated.

\begin{tabular}{lccccc}
\hline & & & & \multicolumn{2}{c}{$\mathrm{IC}_{50}(\mathrm{nM})$} \\
\cline { 5 - 6 } Cell line & P-gp & p53 mutation & Bortezomib & Vincristine & Doxorubicin \\
\hline UKF-NB-3 & - & - & $4.18 \pm 0.74$ & $0.27 \pm 0.08$ & $10.5 \pm 2.4$ \\
UKF-NB-3 ${ }^{\text {VVCR }}{ }^{10}$ & + & + & $8.49 \pm 2.07$ & $80.1 \pm 10.6$ & $120 \pm 24$ \\
UKF-NB-3 & + & - & $4.00 \pm 0.32$ & $218 \pm 35$ & $123 \pm 19$ \\
Be(2)-C & + & + & $7.43 \pm 1.29$ & $12.6 \pm 2.1$ & $381 \pm 51$ \\
IMR-32 & - & - & $4.13 \pm 0.29$ & $0.39 \pm 0.04$ & $16.4 \pm 2.8$ \\
\hline
\end{tabular}

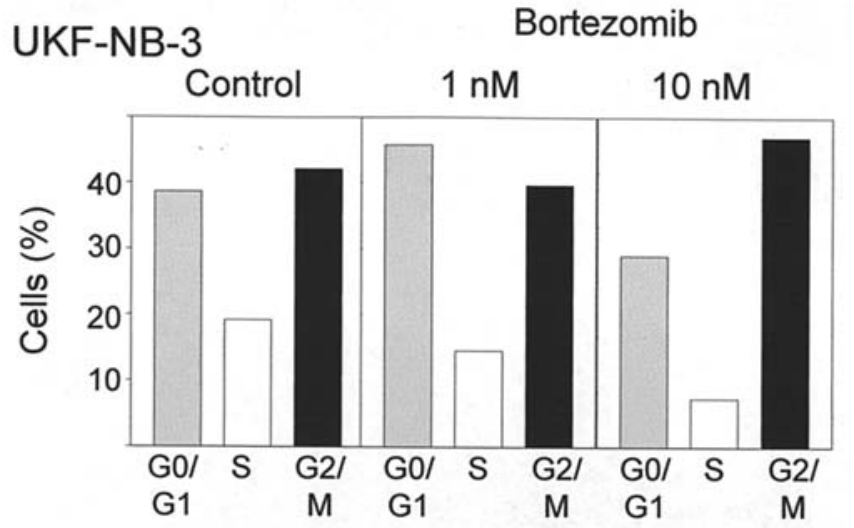

UKF-NB-3VCR ${ }^{10}$

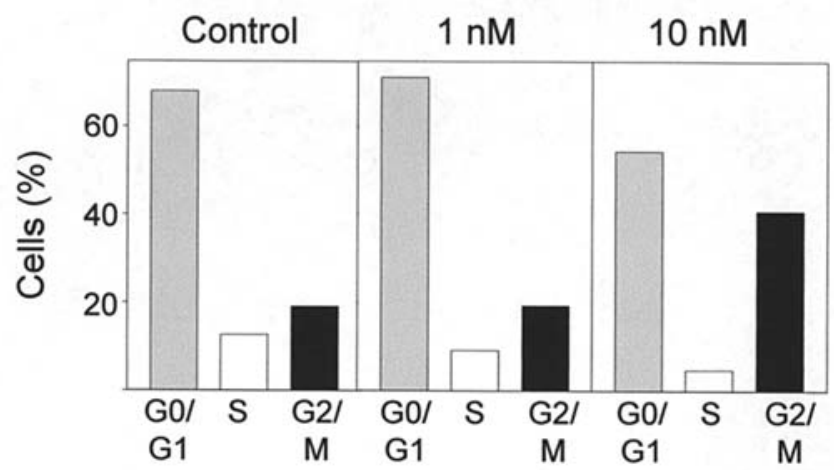

UKF-NB-3'DOX ${ }^{20}$

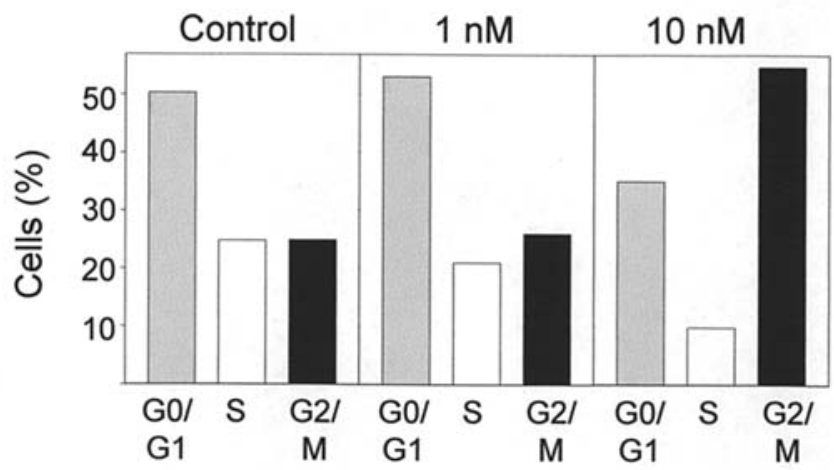

Figure 1. Influence of bortezomib on the cell cycle of neuroblastoma cells. Non-synchronised UKF-NB-3, UKF-NB- $3^{\mathrm{r}} \mathrm{VCR}^{10}$, or UKF-NB-3 ${ }^{\mathrm{r}} \mathrm{DOX}{ }^{20}$ cells were incubated without or with bortezomib $1 \mathrm{nM}$, bortezomib $10 \mathrm{nM}$ for $48 \mathrm{~h}$. The cell cycle distribution was detected in viable cells. The experiment presented is representative for three independent experiments.

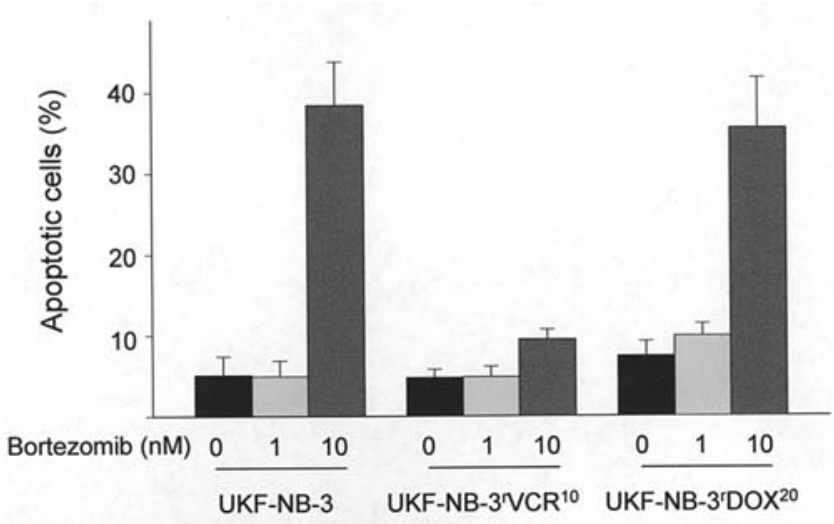

Figure 2. Influence of bortezomib on neuroblastoma cell apoptosis. UKFNB-3, UKF-NB- $3^{\mathrm{r}} \mathrm{VCR}^{10}$, or UKF-NB- $3^{\mathrm{r}} \mathrm{DOX}^{20}$ cells were incubated without or with bortezomib $1 \mathrm{nM}$, bortezomib $10 \mathrm{nM}$ for $48 \mathrm{~h}$. Apoptotic cells were detected as the cells with fractional DNA content ('sub-G1' cell subpopulation). The values are mean \pm SD of three independent experiments.

Bortezomib inhibits neuroblastoma cell cycle and induces apoptosis. Treatment of UKF-NB-3, UKF-NB-3rVCR ${ }^{10}$, and UKF-NB- $3^{\mathrm{r}} \mathrm{DOX}^{20}$ cells with bortezomib $1 \mathrm{nM}$ for $48 \mathrm{~h}$ resulted in a moderate increased number of cells in G0/G1phase. In contrast, bortezomib $10 \mathrm{nM}$ induced a significant cell cycle inhibition by G2/M block (Fig. 1). Bortezomib $1 \mathrm{nM}$ treatment for $48 \mathrm{~h}$ did not significantly affect the number of apoptotic cells as detected by the cell number of the 'sub-G1' population. Bortezomib $10 \mathrm{nM}$ strongly induced apoptosis after $48 \mathrm{~h}$ incubation time (Fig. 2). The pro-apoptotic effect was significantly increased in wild-type p53-expressing UKF-NB-3 and UKF-NB- $3^{\mathrm{r}} \mathrm{DOX}^{20}$ cells compared to p53mutated UKF-NB-3 ${ }^{\mathrm{r}} \mathrm{VCR}{ }^{10}$ cells.

Bortezomib inhibits neuroblastoma xenograft growth. As shown before (12), the tumourigenicity of the chemoresistant cell lines was increased compared to the parental UKF-NB-3 cell line. Of 30 mice injected with UKF-NB-3 cells only three mice developed tumours. These tumours were passaged in vivo and 31 mice were transplanted. From these 31 mice, 13 mice developed tumours, which were used for experiments. In contrast to this, 16 out of 16 UKF-NB- $3^{r} V_{C R}{ }^{10}$ - and 15 out of 16 UKF-NB-3 ${ }^{\text {rDOX }}{ }^{20}$-cell-injected mice developed tumours. 
Table II. Tumour volumes and body weights of bortezomibtreated and control animals at the beginning and at the end of the observation period.

\begin{tabular}{cccc}
$\begin{array}{c}\text { Tumour volume }\left(\mathrm{cm}^{3}\right) \\
(\text { mean } \pm \mathrm{SD})\end{array}$ & & \multicolumn{2}{c}{$\begin{array}{c}\text { Body weight }(\mathrm{g}) \\
(\text { mean } \pm \mathrm{SD})\end{array}$} \\
$\mathrm{I}^{\mathrm{a}}$ & $\mathrm{II}$ & & $\mathrm{I} \quad \mathrm{II}$
\end{tabular}

\begin{tabular}{llllllllllllllll}
\cline { 2 - 5 } Cell line & I $^{\mathrm{a}}$ & II & & I & II \\
\hline
\end{tabular}

\section{UKF-NB-3}

$\begin{array}{lllll}\text { Solvent } & 0.16 \pm 0.12 & 1.94 \pm 1.48 & 30 \pm 3 & 32 \pm 3 \\ \text { Bortezomib } & 0.11 \pm 0.11 & 0.79 \pm 0.86^{\mathrm{b}} & 30 \pm 3 & 32 \pm 2\end{array}$

$\begin{array}{lllll}\text { UKF-NB-3 }^{\mathrm{r} V C R}{ }^{10} & & & & \\ \text { Solvent } & 0.06 \pm 0.03 & 1.88 \pm 1.30 & 27 \pm 2 & 30 \pm 3 \\ \text { Bortezomib } & 0.09 \pm 0.09 & 0.94 \pm 0.81^{\mathrm{b}} & 26 \pm 2 & 25 \pm 4\end{array}$

UKF-NB-3rDOX ${ }^{20}$

$\begin{array}{lllll}\text { Solvent } & 0.07 \pm 0.03 & 3.59 \pm 1.51 & 26 \pm 1 & 30 \pm 2 \\ \text { Bortezomib } & 0.07 \pm 0.04 & 1.28 \pm 0.87^{\mathrm{b}} & 28 \pm 2 & 28 \pm 1\end{array}$

a, day 0 of treatment; II, last day of observation period (day 23 for UKF-NB-3, day 20 for UKF-NB- $3^{\text {r }} V_{C R}{ }^{10}$, day 16 for UKF-NB$\left.3^{\mathrm{r}} \mathrm{DOX}{ }^{20}\right)$. ${ }^{\mathrm{b}}$ Significant $(\mathrm{p}<0.05)$ to corresponding control.

Bortezomib treatment resulted in decreased body weights in the bortezomib-treated mice compared to saline-treated tumour-bearing control animals. Body weights at the beginning and the end of treatment are shown in Table II. Relative body weights of mice during treatment are shown in Fig. 3. In UKF-NB-3- and UKF-NB-3 ${ }^{\mathrm{r}} \mathrm{CR}^{10}$-xenograft bearing mice, the loss of body weight was accompanied by diarrhea. No differences in the blood parameters were observed between bortezomib-treated and control animals (data not shown) except for UKF-NB-3 tumour bearing animals. In this group, bortezomib treatment resulted in a reduction of platelet counts to $50 \%$ of controls at days 4 and 10 after initiation of therapy (data not shown).

Bortezomib inhibited tumour growth of all three cell lines investigated. Tumour volumes in $\mathrm{cm}^{3}$ at the beginning and at the end of treatment are shown in Table II. Single tumour growth curves with relative tumour volumes are presented in Fig. 4. In vivo growth of all three cell lines was significantly inhibited by $2-3$-fold. In contrast to the in vitro results, no decisive difference could be detected between the influence of bortezomib on the in vivo growth of the cell lines UKFNB-3, UKF-NB- $3^{\mathrm{r}} \mathrm{VCR}^{10}$, and UKF-NB- $3^{\mathrm{r} D O X^{20}}$. Notably, tumour growth was totally suppressed in two out of eight UKF-NB- $3^{r} V_{C R}{ }^{10}$-tumour bearing mice but in none of the animals with UKF-NB-3 or UKF-NB- $3^{\mathrm{r}}$ DOX ${ }^{20}$ tumours.

Influence of bortezomib on the tumour histology. The influence of bortezomib on the number of mitoses, apoptotic cells, or infiltrative tumour growth is shown in Table III. Representative haematoxylin/eosin-stained tumour slides are shown in Fig. 5. Bortezomib treatment resulted in a decreased number of mitoses and decreased infiltrative growth in UKF-NB-3, UKF-NB- $3^{\mathrm{r}} \mathrm{VCR}^{10}$, and UKF-NB-3 ${ }^{\mathrm{r}} \mathrm{DOX}{ }^{20}$ tumours. In contrast to the in vitro results, bortezomib increased the number of apoptotic cells in UKF-NB- $3^{\mathrm{r}} \mathrm{VCR}^{10}$ xenografts, whereas the number of apoptotic cells was only slightly or not affected in UKF-NB-3 or UKF-NB-3rDOX ${ }^{20}$ tumours. The growth of the different tumours was associated with different extents of necrosis. For UKF-NB-3 control tumours the necrotic area was $\leq 10 \%$ of the investigated visual fields in all seven tumours. In contrast, three out of six bortezomib-treated UKF-NB-3 tumours had necrotic areas $>10 \%$. The growth of UKF-NB- $3^{\mathrm{r}} \mathrm{VCR}^{10}$ xenografts was characterised by increased and less homogeneous necrosis. Five out of eight tumours had necrotic areas of $\leq 20 \%$ and three tumours had necrotic areas $>20 \%$. Five out of eight bortezomib-treated UKF-NB-3 ${ }^{\mathrm{r}} \mathrm{VCR}^{10}$ tumours had necrotic areas $>20 \%$, and three tumours had necrotic areas $\leq 20 \%$. Necrotic areas in UKF-NB- $3^{r} D^{20}{ }^{20}$ tumours were $\leq 5 \%$ in five out of seven control animals and in five out of eight bortezomib-treated animals. Determination of the mean values of the necrotic areas resulted in a non-significant increase of necrotic areas in bortezomib-treated animals compared to control animals (data not shown).

To investigate the effects of bortezomib on angiogenesis, we quantified tumour microvessel densities in sections from the control and bortezomib-treated neuroblastoma tumours by staining them with an antibody to murine CD31. Significant
UKF-NB-3

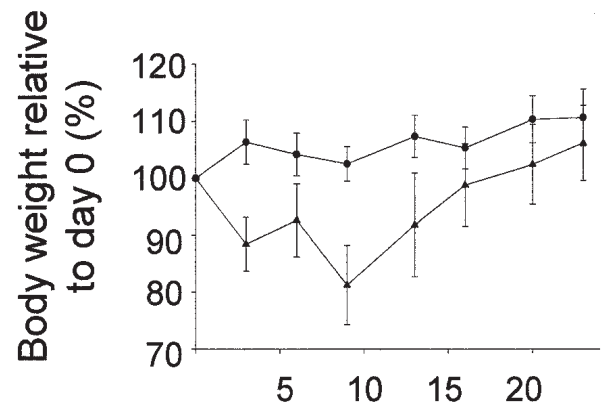

UKF-NB-3rVCR ${ }^{10}$

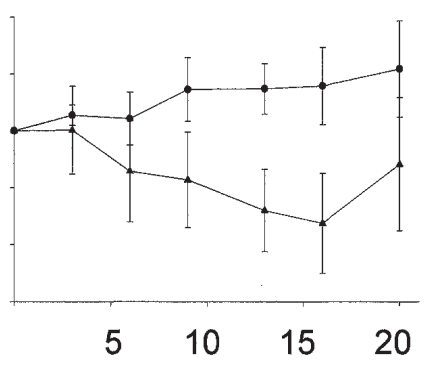

\section{UKF-NB-3rDOX ${ }^{20}$}

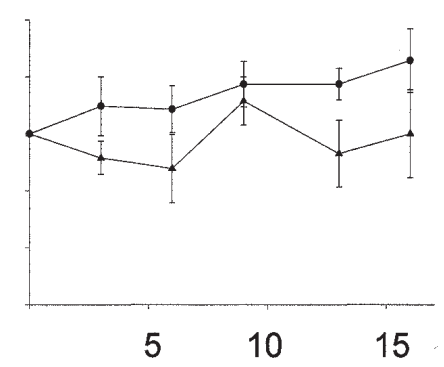

Figure 3. Influence of bortezomib-treatment on the body weights of nude mice. UKF-NB-3, UKF-NB-3 ${ }^{\text {rVCR }}{ }^{10}$, or UKF-NB-3 $3^{\text {rDOX }}{ }^{20}$-tumour bearing mice received six tail vein injections of bortezomib $(1 \mathrm{mg} / \mathrm{kg}$ in $200 \mu 1$ of saline, $\mathbf{\Delta})$ or of saline $(200 \mu 1, \bullet)$ at day $0,3,6,9,12$, and 15 . Body weights are relative to day 0 in $\%$. Values are mean \pm SD of 6-8 animals. 


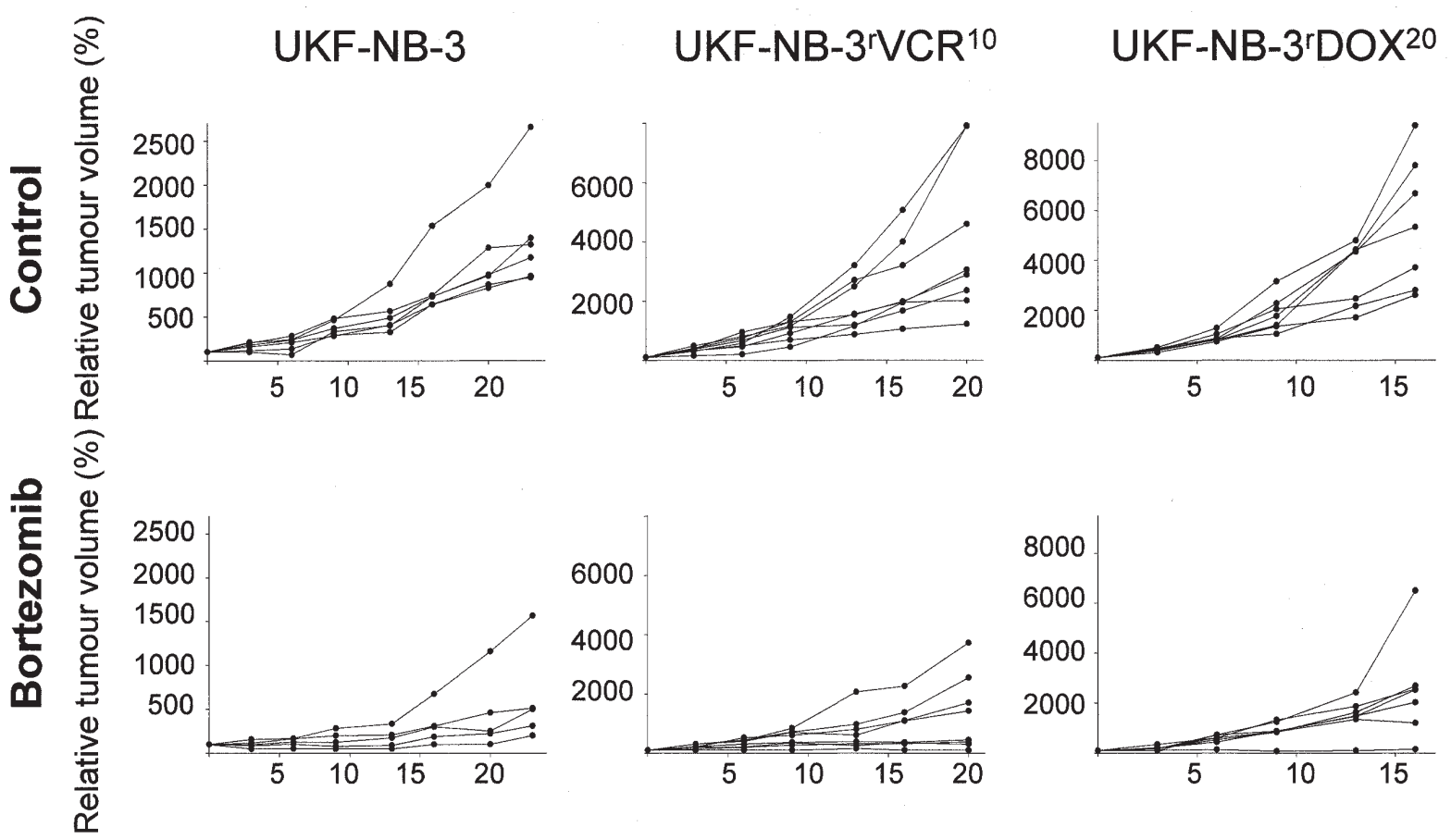

Figure 4. Influence of bortezomib on neuroblastoma xenograft growth in nude mice. UKF-NB-3, UKF-NB-3 ${ }^{\mathrm{r}} \mathrm{VCR}{ }^{10}$, or UKF-NB-3 $3^{\mathrm{r} D O X^{20}}$-tumour bearing $^{2}$ mice received six tail vein injections of bortezomib $(1 \mathrm{mg} / \mathrm{kg}$ in $200 \mu 1$ of saline) or of saline $(200 \mu 1$, control) at day $0,3,6,9$, 12, and 15 . Single tumour growth curves are expressed as volumes relative to the tumour volume at day 0 in $\%$.

Table III. Influence of bortezomib on tumour cell mitoses, apoptosis, and infiltrative growth.

\begin{tabular}{|c|c|c|c|c|c|c|c|}
\hline \multirow[b]{3}{*}{ Cell line } & \multirow[b]{3}{*}{ Grade } & \multirow{2}{*}{\multicolumn{2}{|c|}{$\begin{array}{c}\text { Mitoses }^{\mathrm{a}} \\
\text { Bortezomib }\end{array}$}} & \multirow{2}{*}{\multicolumn{2}{|c|}{$\frac{\text { Apoptotic cells }}{\text { Bortezomib }}$}} & \multirow{2}{*}{\multicolumn{2}{|c|}{$\frac{\text { Infiltrative growth }}{\text { Bortezomib }}$}} \\
\hline & & & & & & & \\
\hline & & - & + & - & + & - & + \\
\hline \multirow[t]{4}{*}{ UKF-NB-3 } & 0 & $0 / 7$ & $0 / 6$ & $0 / 7$ & $0 / 6$ & $0 / 7$ & $1 / 6$ \\
\hline & Low & $0 / 7$ & $0 / 6$ & $0 / 7$ & $0 / 6$ & $3 / 7$ & $4 / 6$ \\
\hline & Middle & $1 / 7$ & $4 / 6$ & $1 / 7$ & $0 / 6$ & $4 / 7$ & $1 / 6$ \\
\hline & High & $6 / 7$ & $2 / 6$ & $6 / 7$ & $6 / 6$ & $0 / 7$ & $0 / 6$ \\
\hline \multirow[t]{4}{*}{ UKF-NB-3 ${ }^{r} V_{C R}{ }^{10}$} & 0 & $0 / 8$ & $0 / 8$ & $0 / 8$ & $0 / 8$ & $2 / 8$ & $5 / 8$ \\
\hline & Low & $0 / 8$ & $0 / 8$ & $0 / 8$ & $0 / 8$ & $4 / 8$ & $3 / 8$ \\
\hline & Middle & $3 / 8$ & $7 / 8$ & $8 / 8$ & $3 / 8$ & $2 / 8$ & $0 / 8$ \\
\hline & High & $5 / 8$ & $1 / 8$ & $0 / 8$ & $5 / 8$ & $0 / 8$ & $0 / 8$ \\
\hline \multirow[t]{4}{*}{ UKF-NB-3rDOX ${ }^{20}$} & 0 & $0 / 7$ & $0 / 8$ & $0 / 7$ & $0 / 8$ & $0 / 7$ & $1 / 8$ \\
\hline & Low & $0 / 7$ & $0 / 8$ & $0 / 7$ & $0 / 8$ & $5 / 7$ & $7 / 8$ \\
\hline & Middle & $1 / 7$ & $3 / 8$ & $0 / 7$ & $0 / 8$ & $2 / 7$ & $0 / 8$ \\
\hline & High & $6 / 7$ & $5 / 8$ & $7 / 7$ & $8 / 8$ & $0 / 7$ & $0 / 8$ \\
\hline
\end{tabular}

${ }^{a}$ Number of animals with tumours showing no (0), low, middle, or high grade mitoses, apoptotic cells, or infiltrative growth.

reductions in CD31 staining were observed in all three neuroblastoma xenografts. Bortezomib treatment reduced the vessel density of UKF-NB-3 tumours by $30 \pm 12 \%$, of UKF-NB- $3^{\mathrm{r}} \mathrm{VCR}^{10}$ tumours by $62 \pm 27 \%$, and of UKF-NB- $3^{\mathrm{r} D O X}{ }^{20}$ tumours by $25 \pm 10 \%$. Representative photographs of UKF-NB$3^{\mathrm{r} V C R}{ }^{10}$ tumour slices stained for CD31 are shown in Fig. 6. 


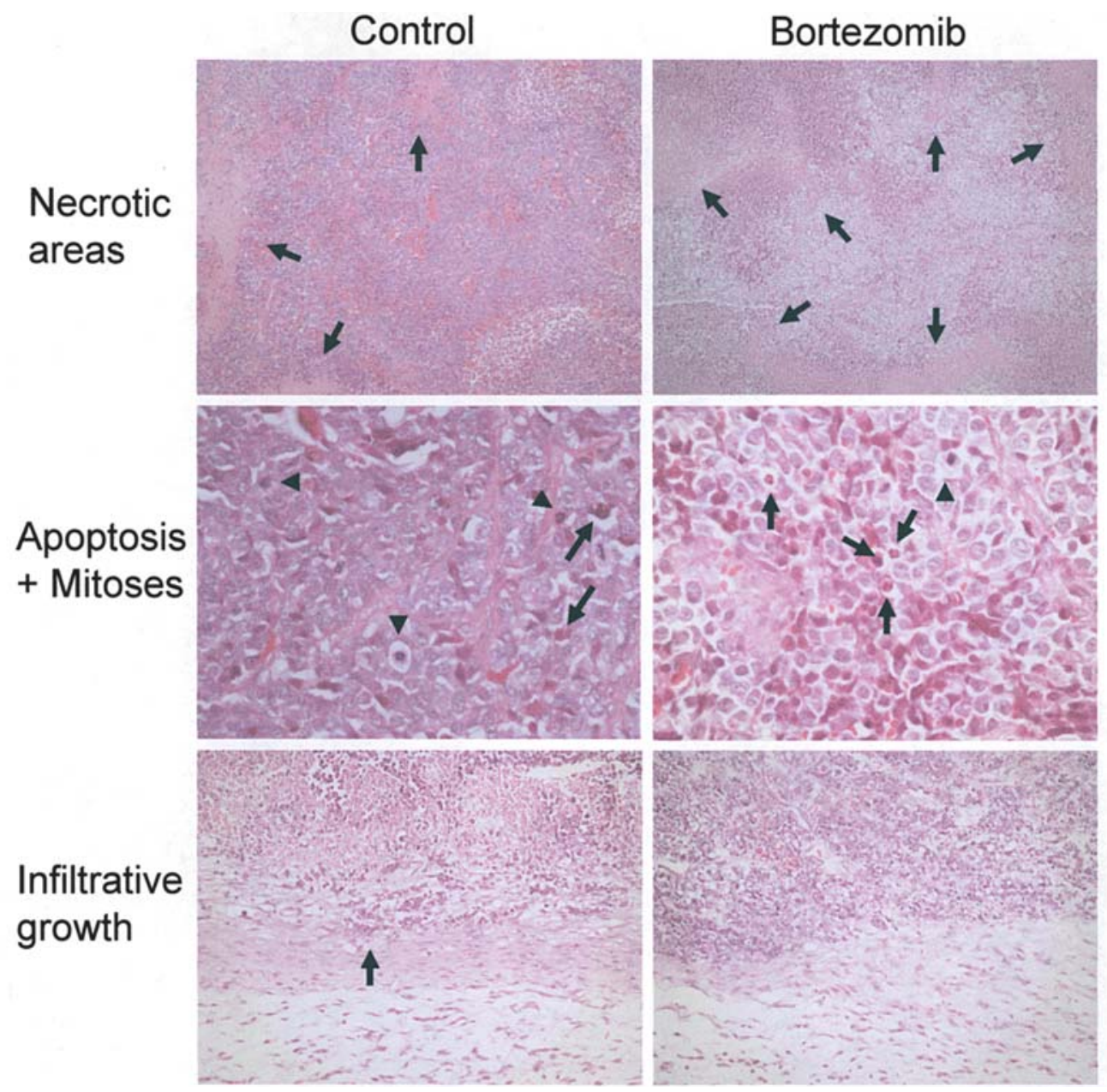

Figure 5. Influence of bortezomib on the neuroblastoma histology. Representative photographs showing saline-treated (control) and bortezomib-treated UKFNB- $3^{r} \mathrm{VCR}^{10}$ tumours. Arrows indicate necrotic areas (indicated by homogeneous eosinophilic areas), apoptotic cells (indicated by cell shrinkage and condensed chromosomes), or infiltrative growth in to the surrounding tissue, respectively. Arrowheads indicate mitoses (indicated by mitotic figures consisting of condensed chromosomes).

Control

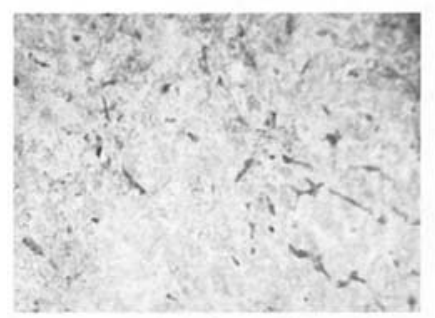

Figure 6. Influence of bortezomib on neuroblastoma angiogenesis Representative photographs showing bortezomib-treated and saline-treated (control) UKF-NB- ${ }^{r} V_{C R}{ }^{10}$ tumour tissues with dark anti-CD31-antibody stained microvessels.

\section{Discussion}

Bortezomib is a selective inhibitor of the $26 \mathrm{~S}$ proteasome, a critical nuclear and cytoplasmic proteolytic system that regulates cell proliferation, differentiation, and apoptosis (5). Our data demonstrate that bortezomib inhibits growth of chemosensitive and chemoresistant neuroblastoma cells in vitro and in vivo. The in vitro $\mathrm{IC}_{50}$ values ranging from 4 to $8.5 \mathrm{nM}$ were in the range of achievable plasma concentrations $>1 \mu \mathrm{M}$ (6). Bortezomib had been shown before to overcome drug resistances in multiple myeloma cell lines (23). Conflicting data exist on the influence of p53 mutation on the cytotoxic activity of bortezomib. Several studies showed that bortezomib acts on cancer cells independently of the cellular p53 status $(5,23-27)$. Other studies reported that the anticancer mechanism of bortezomib involves p53 activation and stabilisation $(26,28)$ and p53 inactivation reduced the sensitivity of non-small cell lung cancer cells and prostate cancer cells to bortezomib $(29,30)$. Our results indicate an about 2-fold decreased sensitivity of p53-mutated neuroblastoma cells $\left(\mathrm{Be}(2)-\mathrm{C}\right.$, UKF-NB- $\left.3^{\mathrm{r}} \mathrm{VCR}^{10}\right)$ compared to neuroblastoma cells expressing wild-type p53 (IMR-32, UKFNB-3, UKF-NB- $3^{\mathrm{r} D O X^{20}}$ ). Since the investigation of a direct contribution of p53 to bortezomib-induced anti-cancer effects was not part of our study, it cannot be definitely concluded if p53 mutation is responsible for the decreased sensitivity of $\mathrm{Be}(2)-\mathrm{C}$ and UKF-NB- $3^{\mathrm{r}} \mathrm{VCR}^{10}$ cells to bortezomib treatment.

Bortezomib-induced cell cycle inhibition and apoptosis was described in different cancer cell lines (23,24,27-29). While high bortezomib concentrations induced a G2/M cell cycle block $(23,24,27-29)$, bortezomib concentrations that did not significantly inhibit cell proliferation resulted in a 
moderate G0/G1 arrest (28). In concordance, treatment of UKF-NB-3, UKF-NB- $3^{\text {rVCR }}{ }^{10}$, and UKF-NB- $3^{r}$ DOX $^{20}$ cells with bortezomib $1 \mathrm{nM}$ for $48 \mathrm{~h}$ caused a limited accumulation of viable cells in $\mathrm{G} 0 / \mathrm{G} 1$-phase whereas treatment of all three cell lines with bortezomib $10 \mathrm{nM}$ for $48 \mathrm{~h}$ resulted in a significant G2/M block. In addition, bortezomib treatment induced apoptosis in all three cell lines. Apoptosis induction was more pronounced in the wild-type p53-expressing cell lines UKF-NB-3 and UKF-NB-3 ${ }^{\mathrm{r}} \mathrm{DOX}^{20}$ compared to $\mathrm{p} 53-$ mutated UKF-NB- $3^{\mathrm{r}} \mathrm{VCR}{ }^{10}$ cells. In principle, this finding is in concert with the increased $\mathrm{IC}_{50}$ values of bortezomib in p53-mutated neuroblastoma cells. However, the differences in the sensitivity to bortezomib-induced apoptosis between p53-positive and p53-negative cells are clearly higher than the differences in the cell viability indicated by the $\mathrm{IC}_{50}$ values. Possibly, other cell death mechanisms than apoptosis that are not associated with DNA fragmentation such as autophagia may contribute to the strong differences in the $\mathrm{IC}_{50}$ values (31).

In vivo investigations revealed that bortezomib inhibited the growth of UKF-NB-3, UKF-NB- $3^{\text {rVCR }}{ }^{10}$, and UKF-NB$3^{\mathrm{r}} \mathrm{DOX}^{20}$ xenografts. In contrast to the in vitro results, which demonstrated the p53-mutated UKF-NB- $3^{r} \mathrm{VCR}^{10}$ to be less sensitive to bortezomib than UKF-NB-3 or UKF-NB$3^{\text {r }} \mathrm{DOX}^{20}$ cells, bortezomib totally inhibited tumour growth of two out of eight UKF-NB- $3^{\text {r }} V_{C R}{ }^{10}$ tumours but not of other tumours. Bortezomib had been shown before to inhibit tumour growth, angiogenesis, and metastases and to induce cytotoxicity to tumour cells in different in vivo tumour models (7,24,25,32-39). In our experiments, bortezomib inhibited neuroblastoma growth as indicated by the number of mitoses and infiltrative tumour growth in all three xenografts grown in nude mice. In addition, bortezomib significantly inhibited vessel formation of all three tumours. The strongest effect of bortezomib was seen on UKF-NB- $3^{r} V_{C R}{ }^{10}$ xenografts (62 $\pm 27 \%$ inhibition of angiogenesis) compared to UKF-NB-3 ( $30 \pm 12 \%$ inhibition) or UKF-NB- $3^{\mathrm{r} D O X^{20}}(25 \pm 10 \%$ inhibition). Although the in vitro results indicated the lowest sensitivity of UKF-NB- $3^{\text {r }} \mathrm{VCR}^{10}$ cells to bortezomib-induced apoptosis, increased apoptosis in response to bortezomib treatment could solely detected in UKF-NB- $3^{r} \mathrm{VCR}^{10}$ tumours. Therefore, increased apoptosis of UKF-NB- $3^{r} \mathrm{VCR}^{10}$ cells in vivo is more likely to be attributed to the bortezomib-induced angiogenesis inhibition than to direct effects of bortezomib on UKF-NB- ${ }^{\mathrm{r}} \mathrm{VCR}^{10}$ cells in vivo and angiogenesis inhibition may play a central role in bortezomib-induced neuroblastoma growth inhibition in our models. The low incidence of bortezomib-induced apoptosis in vivo is in concert with our results and results of others showing that apoptosis induction is often not the main mechanism for cancer cell death in vivo and that the in vivo action of only few anti-cancer drugs correlates with the cellular p53-status (40-42).

The systemic application of bortezomib was associated with known adverse effects including body weight loss, diarrhea, and thrombopenia in our experiments $(36,38,39,43,44)$. A recent phase I study of bortezomib in paediatric patients with refractory solid tumours (including two patients with neuroblastoma) demonstrated that the drug is well tolerated with minimal systemic toxicity (11) and dose-dependent inhibition of the 20S proteasome activity was found in this phase I trial after drug administration. On the basis of the encouraging preliminary results of adult clinical trials, the favourable toxicity profile of bortezomib in phase I clinical trials in paediatric patients, and our preclinical results on multi-drug resistant neuroblastoma cells it appears reasonable to pursue additional paediatric development of the drug.

\section{Acknowledgements}

The authors thank the friendly society 'Hilfe für krebskranke Kinder Frankfurt e.V.' and their foundation 'Frankfurter Stiftung für krebskranke Kinder' for support. The in vitro experiments were performed with the excellent technical support of Sofia Aidanopolou and the animal experiments were performed with the excellent technical support of B. Büttner and S. Gromova.

\section{References}

1. Ladenstein R, Philip T, Lasset C, Hartmann O, Garaventa A, Pinkerton R, Michon J, Pritchard J, Klingebiel T, Kremens B, Pearson A, Coze C, Paolucci P, Frappaz D, Gadner H and Chauvin F: Multivariate analysis of risk factors in stage 4 neuroblastoma patients over the age of one year treated with megatherapy and stem-cell transplantation: a report from the European Bone Marrow Transplantation Solid Tumor Registry. J Clin Oncol 16: 953-965, 1998.

2. Matthay KK, Villablanca JG, Seeger RC, Stram DO, Harris RE, Ramsay NK, Swift P, Shimada H, Black CT, Brodeur GM, Gerbing RB and Reynolds CP: Treatment of high-risk neuroblastoma with intensive chemotherapy, radiotherapy, autologous bone marrow transplantation, and 13-cis-retinoic acid. Children's Cancer Group. N Engl J Med 341: 1165-1113, 1999.

3. Weinstein JL, Katzenstein HM and Cohn SL: Advances in the diagnosis and treatment of neuroblastoma. Oncologist 8: 278-292, 2003.

4. Keshelava N, Seeger RC, Groshen S and Reynolds CP: Drug resistance patterns of human neuroblastoma cell lines derived from patients at different phases of therapy. Cancer Res 58: 5396-5405, 1998

5. Adams J: The development of proteasome inhibitors as anticancer drugs. Cancer Cell 5: 417-421, 2004.

6. Rajkumar SV, Richardson PG, Hideshima T and Anderson KC: Proteasome inhibition as a novel therapeutic target in human cancer. J Clin Oncol 23: 630-639, 2005.

7. Williams S, Pettaway C, Song R, Papandreou C, Logothetis C and McConkey DJ: Differential effects of the proteasome inhibitor bortezomib on apoptosis and angiogenesis in human prostate tumor xenografts. Mol Cancer Ther 2: 835-843, 2003.

8. Richardson PG, Mitsiades C, Hideshima T and Anderson KC: Proteasome inhibition in the treatment of cancer. Cell Cycle 4: 290-296, 2005.

9. Tan TT, Degenhardt K, Nelson DA, Beaudoin B, Nieves-Neira W, Bouillet P, Villunger A, Adams JM and White E: Key roles of BIM-driven apoptosis in epithelial tumors and rational chemotherapy. Cancer Cell 7: 227-238, 2005.

10. Richardson PG, Barlogie B, Berenson J, Singhal S, Jagannath S, Irwin D, Rajkumar SV, Srkalovic G, Alsina M, Alexanian R, Siegel D, Orlowski RZ, Kuter D, Limentani SA, Lee S, Hideshima T, Esseltine DL, Kauffman M, Adams J, Schenkein DP and Anderson KC: A phase 2 study of bortezomib in relapsed, refractory myeloma. N Engl J Med 348: 2609-2617, 2003.

11. Blaney SM, Bernstein M, Neville K, Ginsberg J, Kitchen B, Horton T, Berg SL, Krailo M and Adamson PC: Phase I study of the proteasome inhibitor bortezomib in pediatric patients with refractory solid tumors: a Children's Oncology Group study (ADVL0015). J Clin Oncol 22: 4804-4809, 2004.

12. Kotchetkov R, Hernáiz Driever P, Cinatl J, Michaelis M, Karaskova J, Blaheta RA, Squire JA, von Deimling A, Moog J and Cinatl J Jr: Increased malignant behavior in neuroblastoma cells with acquired multi-drug resistance does not depend on P-gp Expression. Int J Oncol 27: 1029-1037, 2005. 
13. Cinatl J Jr, Cinatl J, Kotchetkov R, Matousek J, Woodcock BG, Koehl U, Vogel JU, Kornhuber B and Schwabe D: Bovine seminal ribonuclease exerts selective cytotoxicity toward neuroblastoma cells both sensitive and resistant to chemotherapeutic drugs. Anticancer Res 20: 853-859, 2000.

14. Michaelis M, Cinatl J, Vogel JU, Pouckova P, Hernáiz Driever P and Cinatl J Jr: Treatment of drug-resistant human neuroblastoma cells with cyclodextrin inclusion complexes of aphidicolin. Anticancer Drugs 12: 467-473, 2001.

15. Kotchetkov R, Cinatl J, Blaheta R, Vogel JU, Karaskova J, Squire J, Hernáiz Driever P, Klingebiel T and Cinatl J Jr: Development of resistance to vincristine and doxorubicin in neuroblastoma alters malignant properties and induces additional karyotype changes: a preclinical model. Int J Cancer 104: 36-43, 2003.

16. LaQuaglia MP, Kopp EB, Spengler BA, Meyers MB and Biedler JL: Multidrug resistance in human neuroblastoma cells. J Pediatr Surg 26: 1107-1112, 1991

17. Cinatl J Jr, Cinatl J, Kotchetkov R, Vogel JU, Woodcock BG, Matousek J, Pouckova P and Kornhuber B: Bovine seminal ribonuclease selectively kills human multidrug-resistant neuroblastoma cells via induction of apoptosis. Int J Oncol 15: 1001-1009, 1999.

18. Tweddle DA, Malcolm AJ, Bown N, Pearson AD and Lunec J: Evidence for the development of p53 mutations after cytotoxic therapy in a neuroblastoma cell line. Cancer Res 61: 8-13, 2001.

19. Russell J, Wheldon TE and Stanton P: A radioresistant variant derived from a human neuroblastoma cell line is less prone to radiation-induced apoptosis. Cancer Res 55: 4915-4921, 1995.

20. Tweddle DA, Pearson AD, Haber M, Norris MD, Xue C, Flemming $\mathrm{C}$ and Lunec $\mathrm{J}$ : The p53 pathway and its inactivation in neuroblastoma. Cancer Lett 197: 93-98, 2003.

21. Mosmann T: Rapid colorimetric assay for cellular growth and survival: application to proliferation and cytotoxicity assays. J Immunol Methods 65: 55-63, 1983

22. Michaelis M, Suhan T, Cinatl J, Hérnaiz Driever P and Cinatl J Jr: Valproic acid and interferon-alpha synergistically inhibit neuroblastoma cell growth in vitro and in vivo. Int J Oncol 25: 1795-1799, 2004.

23. Hideshima T, Richardson P, Chauhan D, Palombella VJ, Elliott PJ, Adams J and Anderson KC: The proteasome inhibitor PS-341 inhibits growth, induces apoptosis, and overcomes drug resistance in human multiple myeloma cells. Cancer Res 61: 3071-3076, 2001

24. Adams J, Palombella VJ, Sausville EA, Johnson J, Destree A, Lazarus DD, Maas J, Pien CS, Prakash S and Elliott PJ: Proteasome inhibitors: a novel class of potent and effective antitumor agents. Cancer Res 59: 2615-2622, 1999.

25. Cusack JC Jr, Liu R, Houston M, Abendroth K, Elliott PJ, Adams J and Baldwin AS Jr: Enhanced chemosensitivity to CPT-11 with proteasome inhibitor PS-341: implications for systemic nuclear factor-kappaB inhibition. Cancer Res 61: 3535-3540, 2001

26. Yu J, Tiwari S, Steiner P and Zhang L: Differential apoptotic response to the proteasome inhibitor Bortezomib [VELCADE, PS-341] in Bax-deficient and p21-deficient colon cancer cells. Cancer Biol Ther 2: 694-699, 2003.

27. Yin D, Zhou H, Kumagai T, Liu G, Ong JM, Black KL and Koeffler HP: Proteasome inhibitor PS-341 causes cell growth arrest and apoptosis in human glioblastoma multiforme (GBM). Oncogene 24: 344-354, 2005

28. Nasr R, El-Sabban ME, Karam JA, Dbaibo G, Kfoury Y, Arnulf B, Lepelletier Y, Bex F, de The H, Hermine O and Bazarbachi A: Efficacy and mechanism of action of the proteasome inhibitor PS-341 in T-cell lymphomas and HTLV-I associated adult Tcell leukemia/lymphoma. Oncogene 24: 419-430, 2005.

29. Ling YH, Liebes L, Jiang JD, Holland JF, Elliott PJ, Adams J, Muggia FM and Perez-Soler R: Mechanisms of proteasome inhibitor PS-341-induced G(2)-M-phase arrest and apoptosis in human non-small cell lung cancer cell lines. Clin Cancer Res 9: $1145-1154,2003$
30. Williams SA and McConkey DJ: The proteasome inhibitor bortezomib stabilizes a novel active form of p53 in human LNCaP-Pro5 prostate cancer cells. Cancer Res 63: 7338-7344, 2003.

31. Okada H and Mak TW: Pathways of apoptotic and nonapoptotic death in tumour cells. Nat Rev Cancer 4: 592-603, 2004.

32. Teicher BA, Ara G, Herbst R, Palombella VJ and Adams J: The proteasome inhibitor PS-341 in cancer therapy. Clin Cancer Res 5: 2638-2645, 1999

33. Shah SA, Potter MW, McDade TP, Ricciardi R, Perugini RA, Elliott PJ, Adams J and Callery MP: 26S proteasome inhibition induces apoptosis and limits growth of human pancreatic cancer. J Cell Biochem 82: 110-122, 2001.

34. Sunwoo JB, Chen Z, Dong G, Yeh N, Crowl Bancroft C, Sausville E, Adams J, Elliott P and van Waes C: Novel proteasome inhibitor PS-341 inhibits activation of nuclear factor-kappa B, cell survival, tumor growth, and angiogenesis in squamous cell carcinoma. Clin Cancer Res 7: 1419-1428, 2001 .

35. Le Blanc R, Catley LP, Hideshima T, Lentzsch S, Mitsiades CS, Mitsiades N, Neuberg D, Goloubeva O, Pien CS, Adams J, Gupta D, Richardson PG, Munshi NC and Anderson KC: Proteasome inhibitor PS-341 inhibits human myeloma cell growth in vivo and prolongs survival in a murine model. Cancer Res 62: 4996-5000, 2002.

36. Nawrocki ST, Bruns CJ, Harbison MT, Bold RJ, Gotsch BS, Abbruzzese JL, Elliott P, Adams J and McConkey DJ: Effects of the proteasome inhibitor PS-341 on apoptosis and angiogenesis in orthotopic human pancreatic tumor xenografts. Mol Cancer Ther 1: 1243-1253, 2002.

37. Amiri KI, Horton LW, LaFleur BJ, Sosman JA and Richmond A: Augmenting chemosensitivity of malignant melanoma tumors via proteasome inhibition: implication for bortezomib (VELCADE, PS-341) as a therapeutic agent for malignant melanoma. Cancer Res 64: 4912-4918, 2004

38. Satou Y, Nosaka K, Koya Y, Yasunaga JI, Toyokuni S and Matsuoka M: Proteasome inhibitor, bortezomib, potently inhibits the growth of adult T-cell leukemia cells both in vivo and in vitro. Leukemia 18: 1357-1363, 2004.

39. Boccadoro M, Morgan G and Cavenagh J: Preclinical evaluation of the proteasome inhibitor bortezomib in cancer therapy. Cancer Cell Int 5: 18, 2005.

40. Fichtner I, Slisow W, Gill J, Becker M, Elbe B, Hillebrand T and Bibby M: Anticancer drug response and expression of molecular markers in early-passage xenotransplanted colon carcinomas. Eur J Cancer 40: 298-307, 2004.

41. Koike M, Fujita F, Komori K, Katoh F, Sugimoto T, Sakamoto Y, Matsuda M and Fujita M: Dependence of chemotherapy response on p53 mutation status in a panel of human cancer lines maintained in nude mice. Cancer Sci 95: 541-546, 2004.

42. Brown JM and Attardi LD: The role of apoptosis in cancer development and treatment response. Nat Rev Cancer 5: 231-237, 2005.

43. Goy A, Younes A, McLaughlin P, Pro B, Romaguera JE, Hagemeister F, Fayad L, Dang NH, Samaniego F, Wang M, Broglio K, Samuels B, Gilles F, Sarris AH, Hart S, Trehu E, Schenkein D, Cabanillas F and Rodriguez AM: Phase II study of proteasome inhibitor bortezomib in relapsed or refractory Bcell non-Hodgkin's lymphoma. J Clin Oncol 23: 667-675, 2005.

44. O'Connor OA, Wright J, Moskowitz C, Muzzy J, MacGregorCortelli B, Stubblefield M, Straus D, Portlock C, Hamlin P, Choi E, Dumetrescu O, Esseltine D, Trehu E, Adams J, Schenkein D and Zelenetz AD: Phase II clinical experience with the novel proteasome inhibitor bortezomib in patients with indolent non-Hodgkin's lymphoma and mantle cell lymphoma. J Clin Oncol 23: 676-684, 2005. 